\title{
Two Groups of Phytoplasmas from Japan Distinguished on the Basis of Amplification and Restriction Analysis of 16S rDNA
}

Seiichi Okuda, Molecular Plant Pathology Laboratory, Agricultural Research Service, USDA, Beltsville, MD, and Faculty of Agriculture, Utsunomiya University, Utsunomiya 321, Japan; James P. Prince, Robert E. Davis, Ellen L. Dally, and Ing-Ming Lee, Molecular Plant Pathology Laboratory, Agricultural Research Service, USDA, Beltsville, MD 20705; Bradley Mogen, Molecular Plant Pathology Laboratory, Agricultural Research Service, USDA, and Animal and Plant Health Inspection Service, Beltsville, MD; and Shosuke Kato, National Agriculture Research Center, Tsukuba, Ibaraki 305, Japan

\begin{abstract}
Okuda, S., Prince, J. P., Davis, R. E., Dally, E. L., Lee, I.-M., Mogen, B., and Kato, S. 1997. Two groups of phytoplasmas from Japan distinguished on the basis of amplification and restriction analysis of 16S rDNA. Plant Dis. 81:301-305.

Phytoplasmas (mycoplasmalike organisms, MLOs) associated with mitsuba (Japanese honewort) witches'-broom (JHW), garland chrysanthemum witches'-broom (GCW), eggplant dwarf (ED), tomato yellows (TY), marguerite yellows (MY), gentian witches'-broom (GW), and tsuwabuki witches'-broom (TW) in Japan were investigated by polymerase chain reaction (PCR) amplification of DNA and restriction enzyme analysis of PCR products. The phytoplasmas could be separated into two groups, one containing strains JHW, GCW, ED, TY, and MY, and the other containing strains GW and TW, corresponding to two groups previously recognized on the basis of transmission by Macrosteles striifrons and Scleroracus flavopictus, respectively. The strains transmitted by $M$. striifrons were classified in 16S rRNA gene group 16SrI, which contains aster yellows and related phytoplasma strains. Strains GW and TW were classified in group 16SrIII, which contains phytoplasmas associated with peach X-disease, clover yellow edge, and related phytoplasmas. Digestion of amplified 16S rDNA with HpaII indicated that strains GW and TW were affiliated with subgroup 16SrIII-B, which contains clover yellow edge phytoplasma. All seven strains were distinguished from other phytoplasmas, including those associated with clover proliferation, ash yellows, elm yellows, and beet leafhopper-transmitted virescence in North America, and Malaysian periwinkle yellows and sweet potato witches'broom in Asia.
\end{abstract}

Numerous vegetable, ornamental, and medicinal plants in Japan are affected by diseases attributed to phytoplasmas (formerly mycoplasmalike organisms, MLOs) (8-12,16-21,23-25). The phytoplasmas in a number of these diseases are known to be transmitted either by Macrosteles striifrons Anufriev $(=M$. orientalis Virvaste) or Scleroracus flavopictus Ishihara. Two groups of phytoplasmal diseases have been recognized on the basis of these transmission characteristics $(24,25)$. The plant host ranges for both groups are very wide, and some plant species serve as hosts for phytoplasma strains in both groups, necessitating experimental insect transmission trials to determine the group affiliation of the phytoplasmas $(8,10,12,18-21,23-25)$.

Phytoplasmas transmitted by $M$. striifrons, but not those transmitted by S. fla-

Corresponding author: R. E. Davis

E-mail: rdavis@asrr.arsusda.gov

Accepted for publication 18 November 1996.

Publication no. D-1997-0113-05R

This article is in the public domain and not copyrightable. It may be freely reprinted with customary crediting of the source. The American Phytopathological Society, 1997. vopictus, were considered to be strains of aster yellows phytoplasma. This interpretation was supported by the work of Shiomi and Sugiura $(24,25)$, who found that the North American aster yellows vector, M. fascifrons Stal, was capable of transmitting several Japanese phytoplasmas, including the M. striifrons-transmitted mitsuba (Japanese honewort) witches'-broom phytoplasma, and that $M$. striifrons transmitted American aster yellows phytoplasma. The purpose of the present study was to compare the Japanese phytoplasmas with one another and with other Asian phytoplasmas and American strains, including aster yellows phytoplasma, by polymerase chain reaction (PCR) amplification of DNA and restriction analysis of PCR products.

\section{MATERIALS AND METHODS}

Phytoplasma strains and sources. Seven phytoplasma strains were experimentally transmitted by leafhopper vectors from naturally infected plants growing in Japan to plants of Catharanthus roseus (L.) G. Don (Madagascar periwinkle) maintained in a greenhouse in Tsukuba, Japan. The strains and their original field-infected host plants and associated diseases are given in Table 1. Other phytoplasmas, used as reference strains in DNA amplification and restriction analyses in this study, were maintained by grafting in a greenhousegrown white-flowered clonal line of periwinkle at Beltsville, Maryland. As controls, we included in the study reference phytoplasmas representing genomic strain clusters and groups previously described $(3,6,13,14)$. These phytoplasmas included Maryland aster yellows (AY) phytoplasma field-collected from a naturally inoculated plant of periwinkle. The remaining phytoplasmas were in singly infected plants of periwinkle unless otherwise indicated: tomato big bud (BB), clover phyllody $(\mathrm{CPh})$, Canada $\mathrm{X}$-disease $(\mathrm{CX})$, clover yellow edge (CYE) (in Ladino clover), clover proliferation $(\mathrm{CP})$, beet leafhoppertransmitted virescence (VR), ash yellows (AshY1), elm yellows (EY1), goldenrod yellows (GR1), milkweed yellows (MW1), spirea stunt (SP1), northern Italy grapevine phytoplasma (FDU), Malaysian periwinkle yellows (MPY), and sweet potato witches'broom (SPWB).

Polymerase chain reactions. Samples ( $2 \mathrm{~g})$ of leaves were harvested separately from healthy plants or from plants singly infected by phytoplasmas. Total nucleic acid was extracted from each sample by a previously described modification (14) of the procedure of Ausubel et al. (1). The extracted nucleic acid was quantified by spectrophotometry and by agarose gel electrophoresis. Each PCR was carried out as previously described $(2,14)$ using one of the following pairs of oligodeoxyribonucleotide primers in a reaction mixture. Sequences for primer pairs R16F2/R16R2 (F2/R2) (14), r16F4/r16R1 (F4/R1) (2), and $16 \mathrm{R} 758 \mathrm{~F} / 16 \mathrm{R} 1232 \mathrm{R}(758 \mathrm{~F} / 1232 \mathrm{R})(5)$ were derived from a published (15) sequence of the 16S rRNA gene of an Oenothera-infecting phytoplasma. Primer pair G35pm was derived from the nucleotide sequence of a cloned fragment of DNA from the Italian periwinkle virescence phytoplasma (4). Each PCR mixture consisted of a total of $50 \mu$ l that contained 25 ng of total nucleic acid extracted from plants plus $20 \mathrm{pmol}$ of each primer of a pair, 1.25 units of AmpliTaq DNA polymerase (Perkin-Elmer, Foster City, CA), and a final concentration of $0.2 \mathrm{mM}$ each of dATP, dCTP, dGTP, dTTP, 10 mM Tris- 
$\mathrm{HCl}, \mathrm{pH} 8.3,1.5 \mathrm{mM} \mathrm{MgCl}_{2}, 50 \mathrm{mM} \mathrm{KCl}$, and $0.1 \mathrm{mg}$ of gelatin per $\mathrm{ml}$. The reaction mix was overlaid with $25 \mu \mathrm{l}$ of mineral oil. After an initial 2-min incubation at $94^{\circ} \mathrm{C}$, the following conditions were carried out for thirty-five cycles: $94^{\circ} \mathrm{C}$ for $1 \mathrm{~min}, 50^{\circ} \mathrm{C}$ for $2 \mathrm{~min}$, and $72^{\circ} \mathrm{C}$ for $3 \mathrm{~min}$. Following the thirty-five cycles, a final extension step of $7 \mathrm{~min}$ at $72^{\circ} \mathrm{C}$ was carried out. Five $\mu \mathrm{l}$ of reaction mixture was electrophoresed in

Table 1. Source host plants, associated diseases, and geographical origins of phytoplasmas investigated in this study ${ }^{\mathrm{a}}$

\begin{tabular}{|c|c|c|c|c|}
\hline $\begin{array}{l}\text { Phytoplasma } \\
\text { designation }\end{array}$ & Host plant of origin ${ }^{b}$ & Associated disease & Geographic origin ${ }^{c}$ & Reference \\
\hline \multicolumn{5}{|c|}{ Strains transmitted by Macrosteles striifrons (orientalis) } \\
\hline JHW & $\begin{array}{l}\text { Cryptotaenia japonica } \\
\text { Hassk. (Umbelliferae) } \\
\text { [Japanese honewort] }\end{array}$ & $\begin{array}{l}\text { Mitsuba } \\
\text { witches'-broom }\end{array}$ & Yawahara, Ibaraki & 19,21 \\
\hline GCW & $\begin{array}{l}\text { Chrysanthemum } \\
\text { coronarium } \mathrm{L} . \\
\text { (Compositae) }\end{array}$ & $\begin{array}{l}\text { Garland } \\
\text { chrysanthemum } \\
\text { witches'-broom }\end{array}$ & Furukawa, Miyagi & $\begin{array}{l}\text { 20, Kato et } \\
\text { al. (unpubl.) }\end{array}$ \\
\hline ED & $\begin{array}{l}\text { Solanum melongena } \mathrm{L} . \\
\text { (Solanaceae })\end{array}$ & Eggplant dwarf & Toyohashi, Aichi & 8 \\
\hline TY & $\begin{array}{l}\text { Lycopersicon esculentum L. } \\
\text { (Solanaceae) }\end{array}$ & Tomato yellows & Geihoku, Hiroshima & 10 \\
\hline MY & Chrysanthemum frutescens $\mathrm{L}$. & $\begin{array}{l}\text { Marguerite } \\
\text { yellows }\end{array}$ & Tateyama, Chiba & 11 \\
\hline \multicolumn{5}{|c|}{ Strains transmitted by Scleroracus flavopictus } \\
\hline GW & $\begin{array}{l}\text { Gentiana sp. } \\
\quad(\text { Gentianaceae })\end{array}$ & $\begin{array}{l}\text { Gentian } \\
\text { witches'-broom }\end{array}$ & Myokokogen, Niigata & $12,20,23$ \\
\hline TW & $\begin{array}{l}\text { Farfugium japonicum } \\
\text { Kitamura (Compositae) }\end{array}$ & $\begin{array}{l}\text { Tsuwabuki } \\
\text { witches'-broom }\end{array}$ & Nichinan, Miyazaki & 9 \\
\hline
\end{tabular}

${ }^{a}$ The phytoplasmas investigated were transmitted by Macrosteles striifrons (orientalis) or Scleroracus flavopictus in Japan.

${ }^{b}$ Naturally infected field-collected host plant. Common name of plant in brackets. Names in parentheses are families of the host plants.

${ }^{c}$ Geographical locations where phytoplasmas used in the present study were originally collected in the naturally infected host plants.

Table 2. Polymerase chain reaction amplification of DNA sequences from plants of Catharanthus roseus (periwinkle) infected by phytoplasmas

\begin{tabular}{|c|c|c|c|c|}
\hline \multirow[b]{2}{*}{ Phytoplasma $^{a}$} & \multicolumn{4}{|c|}{ DNA amplification with primer pair indicated ${ }^{b}$} \\
\hline & F4/R1 & G35p/m & 758F/1232R & F2/R2 \\
\hline \multicolumn{5}{|c|}{ Japanese phytoplasmas } \\
\hline JHW & + & - & + & + \\
\hline GCW & + & - & + & + \\
\hline ED & + & - & + & + \\
\hline TY & + & - & + & + \\
\hline MY & + & - & + & + \\
\hline GW & + & - & + & + \\
\hline TW & + & - & + & + \\
\hline \multicolumn{5}{|c|}{ Reference phytoplasmas } \\
\hline AY & + & + & + & + \\
\hline BB & + & - & + & + \\
\hline $\mathrm{CPh}$ & + & + & + & + \\
\hline $\mathrm{CP}$ & - & - & + & + \\
\hline AshY1 & - & - & + & + \\
\hline $\mathrm{CX}$ & - & - & + & + \\
\hline CYE & - & - & + & + \\
\hline VR & - & - & + & + \\
\hline EY1 & - & - & + & + \\
\hline SPWB & - & - & + & + \\
\hline MPY & ND & ND & + & + \\
\hline FDU & - & - & + & + \\
\hline GR1 & - & - & + & + \\
\hline MW1 & - & - & + & + \\
\hline SP1 & - & - & + & + \\
\hline
\end{tabular}

${ }^{a}$ Japanese phytoplasma designations are the same as those in Table 1. AY, Maryland aster yellows. $\mathrm{BB}$, tomato big bud. $\mathrm{CPh}$, clover phyllody. CP, clover proliferation. AshY1, ash yellows. CX, Canada X-disease. CYE, clover yellow edge. VR, beet leafhopper-transmitted virescence. EY1, elm yellows. SPWB, sweet potato witches'-broom. MPY, Malaysian periwinkle yellows. FDU, northern Italy grapevine phytoplasma. GR1, goldenrod yellows. MW1, milkweed yellows. SP1, spirea stunt.

$\mathrm{b}^{\mathrm{b}}$, amplification of phytoplasma-specific DNA of approximately $700 \mathrm{bp}, 1.25 \mathrm{kbp}, 490 \mathrm{bp}$, and 1.2 $\mathrm{kbp}$ in reaction mixtures containing primer pairs F4/R1, G35pm, 758F/1232R, and F2/R2, respectively. -, phytoplasma-specific DNA amplification not observed. ND, not determined.

a $1 \%$ agarose gel in $1 \times$ TAE $(0.04 \mathrm{M}$ Tris acetate, $\mathrm{pH} 8.0$, and $0.002 \mathrm{M}$ EDTA) to analyze the PCR products.

Restriction analysis of PCR products. Restriction analysis of PCR-amplified 16S rDNA, used previously as a rapid means to classify phytoplasma strains into groups $(14,16,22)$, was used. Five $\mu$ l of each reaction mix following PCR with primer pair $758 \mathrm{~F} / 1232 \mathrm{R}$ or primer pair $\mathrm{F} 2 / \mathrm{R} 2$ was digested singly with 5 units of the following enzymes: AluI (Boehringer Mannheim, Indianapolis, IN), MseI, KpnI, HhaI, and HpaII (Sigma Chemical Co., St. Louis, MO) using the manufacturers' recommended reaction conditions with the addition of spermidine (Sigma) to a final concentration of $4 \mathrm{mM}$ in a total reaction mixture of $20 \mu \mathrm{l}$. Digests were analyzed by electrophoresis of the $20-\mu 1$ reaction mixture in a $5 \%$ polyacrylamide gel in $0.5 \times$ TBE $(1 \times=0.089 \mathrm{M}$ Tris borate, $0.089 \mathrm{M}$ boric acid, and $0.002 \mathrm{M}$ EDTA). After electrophoresis, gels were stained with ethidium bromide and examined under UV transillumination. Phytoplasma group affiliations were assigned to $16 \mathrm{~S}$ rDNA restriction fragment length polymorphism (RFLP) groups previously described (14).

\section{RESULTS AND DISCUSSION}

Results from PCR amplification of DNA sequences using primer pair F4/R1, primer pair $\mathrm{G} 35 \mathrm{pm}$, primer pair $758 \mathrm{~F} / 1232 \mathrm{R}$, and primer pair F2/R2 are summarized in Table 2. Repeated experiments gave the same results. No DNA amplification was observed in reaction mixtures containing any primer pair when template consisted of DNA from healthy plants. Amplification of a DNA sequence of about $1.25 \mathrm{kbp}$ was observed in reaction mixtures containing primer pair $\mathrm{G} 35 \mathrm{pm}$ when template consisted of DNA from plants infected by AY phytoplasma, but no DNA amplification was observed when template consisted of DNA extracted from healthy plants or from plants infected by BB, CPh, VR, EY1, AshY1, CX, CYE, SPWB, GR1, MW1, SP1, FDU, or CP phytoplasmas, or by any of the seven phytoplasma strains from Japan. With primer pair F4/R1, amplification of a DNA sequence of about $700 \mathrm{bp}$ was observed when template consisted of DNA extracted from plants infected by phytoplasma strains JHW, GCW, ED, TY, and MY from Japan, or by control strains $\mathrm{AY}, \mathrm{BB}$, and $\mathrm{CPh}$; but no amplification was observed when template consisted of DNA from plants infected by GW, TW, EY1, VR, CP, AshY1, CYE, SPWB, GR1, MW1, SP1, FDU, MPY, or CX phytoplasmas. When the PCR was carried out using primer pair $758 \mathrm{~F} / 1232 \mathrm{R}$ or primer pair F2/R2, a DNA sequence of approximately $490 \mathrm{bp}$ or $1.2 \mathrm{kbp}$, respectively, was amplified when template consisted of DNA extracted from plants infected by any of the Japanese phytoplasmas or by any of the reference phytoplasmas. 
Figure 1 shows results from restriction enzyme analysis of the $1.2-\mathrm{kbp} 16 \mathrm{~S}$ rDNA sequence amplified by PCR using primer pair F2/R2. The Japanese phytoplasma strains could be differentiated into two groups on the basis of RFLPs when PCR products were digested with $A l u \mathrm{I}, M s e \mathrm{I}$, or KpnI. One pattern was exhibited by DNA from phytoplasma strains JHW, GCW, ED, TY, and MY, as well as reference strains

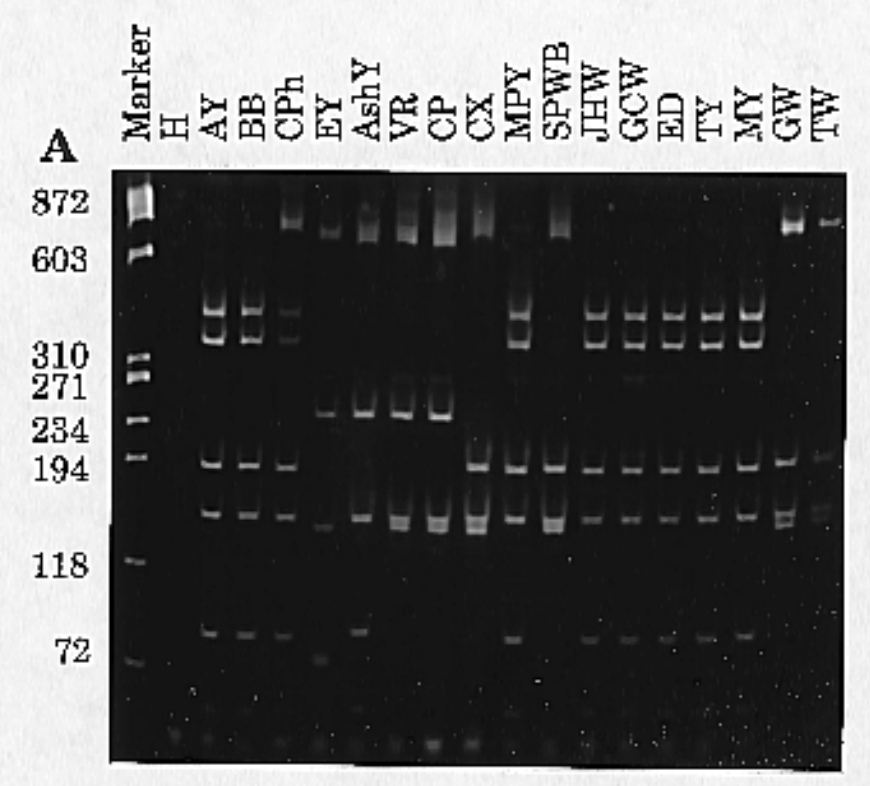

B

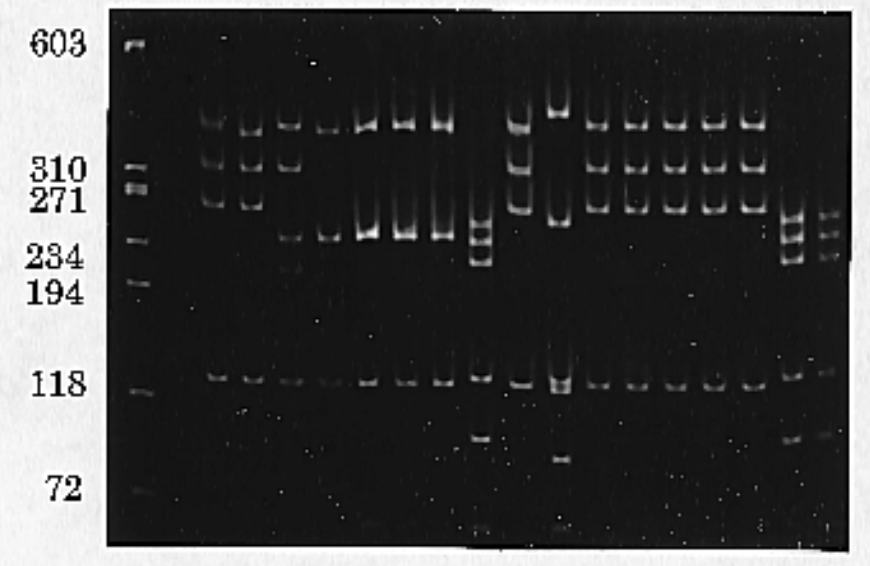

C

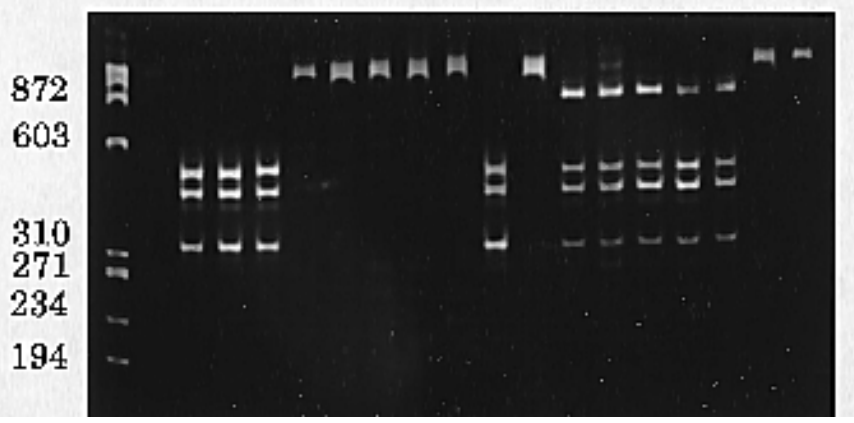

Fig. 1. Restriction fragment length polymorphism analyses of $16 \mathrm{~S}$ rDNA amplified in polymerase chain reactions (PCR) primed by oligonucleotide pair F2/R2. Polyacrylamide gel (5\%) electrophoresis of PCR products digested with (A) Alu1, (B) Mse1, and (C) KpnI. JHW, mitsuba witches'-broom. $\mathrm{GCW}$, garland chrysanthemum witches'-broom. ED, eggplant dwarf. TY, tomato yellows. MY, marguerite yellows. GW, gentian witches'-broom. TW, tsuwabuki witches'-broom. AY, Maryland aster yellows (=MDAY, AY1). BB, tomato big bud. CPh, clover phyllody. AshY1, ash yellows. CX, Canada X-disease. VR, beet leafhopper-transmitted virescence. EY, elm yellows (=EY1). CP, clover proliferation. SPWB, sweet potato witches'-broom. MPY, Malaysian periwinkle yellows. H, healthy periwinkle. S, size standard, phiX174 HaeIII fragments; sizes in bp.

$\mathrm{AY}$ and $\mathrm{BB}$; and the second pattern was exhibited by strains GW and TW, which was identical to that obtained with DNA from reference strain CX. Restriction analysis of the products from PCR primed by oligonucleotide pair $758 \mathrm{~F} / 1232 \mathrm{R}$ distinguished the same two groups (data not shown).

Since $A l u \mathrm{I}$ and $M s e \mathrm{I}$ restriction profiles of $16 \mathrm{~S}$ rDNA from strains $\mathrm{GW}$ and TW were identical to phytoplasmas known to be affiliated with $16 \mathrm{~S}$ rDNA group 16SrIII and the peach $\mathrm{X}$-disease phytoplasma cluster (14), an additional experiment was carried out to determine possible subgroup affiliation of these Japanese phytoplasmas. Figure 2 shows results from MseI and HpaII restriction analysis of $16 \mathrm{~S}$ rDNA amplified in PCR using primer pair F2/R2. Other phytoplasmas recently classified in group 16SrIII (6) were included for comparisons of RFLP patterns. Collective RFLP patterns of the 16S rDNA from GW and TW phytoplasmas were identical, or nearly so, to one another and to those of DNA from phytoplasma strains CYE, MW1, and FDU; but they were distinct from those of $16 \mathrm{~S}$ rDNA from CX, GR1, and SP1 phytoplasmas (Fig. 2).

The Japanese phytoplasmas investigated in this study are associated with diseases that have been extensively researched (812,18-21,23-25). Symptoms observed in field-collected diseased plants and in experimentally infected periwinkle plants were typical of infections by phytoplasmas, and electron microscopy revealed the presence of phytoplasmas in phloem. Data obtained using molecular techniques in the present work are also consistent with the hypothesis that these diseases are caused by phytoplasmas. Amplification of $16 \mathrm{~S}$ rDNA sequences in PCR is consistent with identification of the probable pathogens as phytoplasmas, since primer pairs F4/R1, $758 \mathrm{~F} / 1232 \mathrm{R}$, and F2/R2 were derived from the published sequence (15) of $16 \mathrm{~S}$ rDNA from a phytoplasma infecting Oenothera sp., and detection of phytoplasma DNA by use of these primers in PCR has been demonstrated in other work $(2,5,14)$. The nature of the Japanese plant pathogens as phytoplasmas was further indicated by their similarity with other Asian or North American phytoplasmas in restriction patterns of amplified 16S rDNA.

Both cluster-specific DNA amplification and restriction analysis of PCR-amplified $16 \mathrm{~S}$ rDNA indicated that two distinct groups could be distinguished among the seven Japanese phytoplasmas that we have examined. The present work is the first to document RFLP fingerprints of amplified $16 \mathrm{~S}$ rDNA from these strains. The two strain groups that were distinguished coincided with phytoplasma groups previously designated on the basis of insect transmission (23-25). The complete correspondence between the groups based on molecular data or specificity of insect 
transmission appears to favor the hypothesis that, in contrast to symptoms in diseased plants (13), characteristics of specific transmission by insects can be useful in phytoplasma classifications.

Previous studies indicated that some phytoplasmas occurring in Japan are strains of aster yellows phytoplasma $(8,10,18,20,24,25)$. For example, the transmission of several Japanese phytoplasmas by Macrosteles striifrons (orientalis) $(24,25)$ parallels the well-known transmission of aster yellows phytoplasma by Macrosteles fascifrons, vector of North American aster yellows phytoplasma. Shiomi and Sugiura $(24,25)$ demonstrated that several Japanese phytoplasmas could also be transmitted by $M$. fascifrons, and that an American aster yellows phytoplasma strain could be transmitted by $M$. striifrons. Those findings led to the concept that aster yellows phytoplasma in North America and some phytoplasmas occurring in Japan are related strains $(24,25)$. This concept is consistent with findings in our study. Since $16 \mathrm{~S}$ rDNA from strains JHW, GCW, ED, TY, and MY yielded RFLP patterns that were identical to each other and typical of group $16 \mathrm{SrI}$ phytoplasmas, and since aster yellows strain cluster-specific oligonucleotide pair F4/R1 primed amplification of DNA from these strains, we consider the five Japanese phytoplasmas to be new members of 16SrRNA group 16SrI and the aster yellows phytoplasma strain cluster. In a separate RFLP analysis using HhaI (data not shown), these strains were further identified as members of subgroup 16SrIB. This conclusion is consistent with analysis of $16 \mathrm{~S}$ rRNA gene nucleotide sequence data indicating strain TY to be a member of a phytoplasma group also containing paulownia witches'-broom phytoplasma (17), which belongs to group 16SrI-D (14).

GW and TW phytoplasmas are transmitted by $S$. flavopictus but not by M. striifrons $(12,23)$. Thus, although these strains infect a range of plant species that is similar to the host range of the other five Japanese phytoplasma strains studied here, GW and TW do not appear to be strains of aster yellows phytoplasma on the basis of their insect transmission characteristics (9). Our results are consistent with the view that GW and TW are not strains of aster yellows phytoplasma. Instead, the data indicate that GW and TW phytoplasmas belong to the peach X-disease phytoplasma cluster and group 16SrIII, subgroup III-B.

Although this study distinguished molecular genetic differences between two groups of Japanese phytoplasmas previously separated on the basis of transmission by specific insect vectors, our work did not distinguish between subgroups of phytoplasmas as described by Shiomi and Sugiura (24), who distinguished subgroups among $M$. striifrons-transmitted phyto-

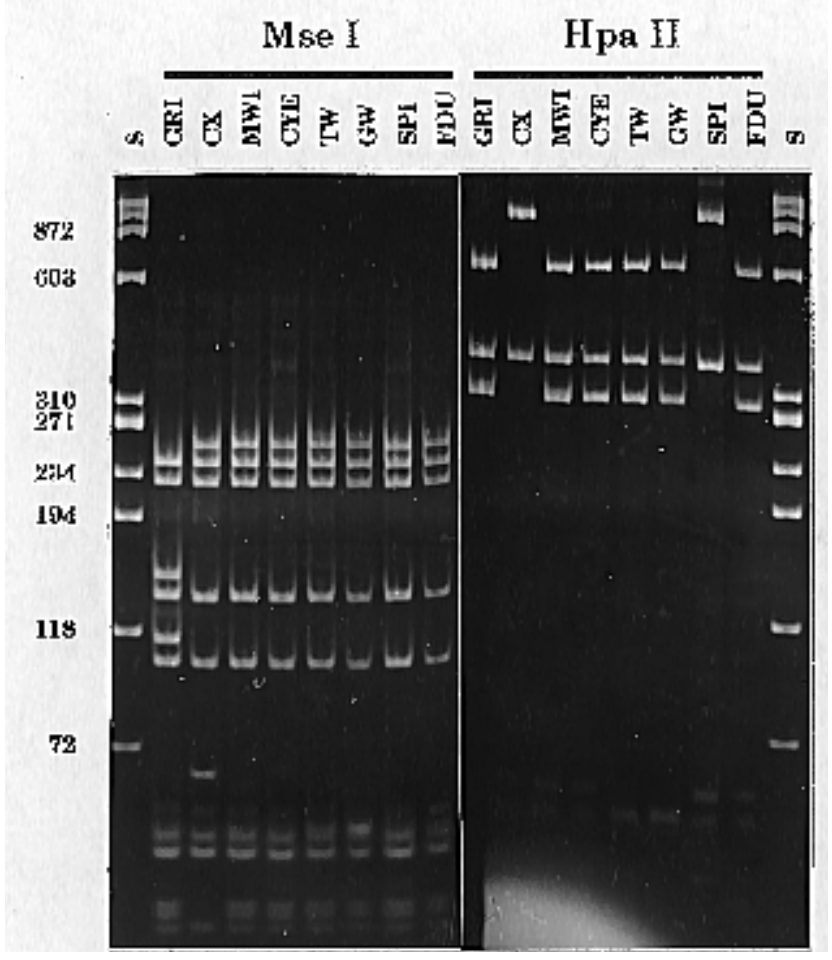

Fig. 2. Restriction fragment length polymorphism analyses of $16 \mathrm{~S}$ rDNA amplified in polymerase chain reactions (PCR). Reaction mixtures contained primer pair F2/R2. Polyacrylamide gel (5\%) electrophoresis of PCR products digested with MseI (left) and HpaII (right). CYE, clover yellow edge. FDU, northern Italy grapevine phytoplasma. SP1, spirea stunt. GR1, goldenrod yellows. MW1, milkweed yellows. Other abbreviations are the same as for Figure 1.

plasma strains on the basis of differential plant host ranges. While it is possible that analysis of highly conserved phytoplasma genes such as $16 \mathrm{~S}$ rDNA provides clues to the identities of unknown insect vectors that may play a role in disease spread, study of polymorphisms in sequences less conserved than $16 \mathrm{~S}$ rDNA will probably be necessary to reveal markers correlated with biological properties such as plant host range and type of symptom(s) induced in susceptible plant species.

\section{ACKNOWLEDGMENTS}

We thank L. Carraro, L. Chiykowski, J. Dale, C. Hiruki, K. L. Khew, G. N. Oldfield, R. Osler, W. A. Sinclair, and H. J. Su for kindly supplying phytoplasmas used in this study. This work was performed in the Molecular Plant Pathology Laboratory (MPPL) while the first author was on sabbatical leave from Utsunomiya University. J. P. Prince was supported by a USDA-ARS Postdoctoral Research Associateship in the MPPL. Work by B. D. Mogen was supported by the USDA-APHIS Postdoctoral Research Associateship Program.

\section{LITERATURE CITED}

1. Ausubel, F. M., Brent, R., Kingston, R. E., Moore, D. D., Seidman, J. G., Smith, J. A., and Struhl, K. 1987. Current Protocols in Molecular Biology. Wiley Interscience, New York.

2. Davis, R. E., and Lee, I.-M. 1993. Clusterspecific polymerase chain reaction amplification of 16S rDNA sequences for detection and identification of mycoplasmalike organisms. Phytopathology 83:1008-1011.

3. Davis, R. E., and Lee, I.-M. 1993. Pathogenicity of spiroplasmas, mycoplasmalike organisms, and vascular-limited fastidious walled bacteria. Pages 491-513 in: Phytopathogenic Bacteria, vol. 1. M. Mount and G. Lacy, eds. Academic Press, New York.

4. Davis, R. E., Prince, J. P., Hammond, R. W., Dally, E. L., and Lee, I.-M. 1992. Polymerase chain reaction detection of Italian periwinkle virescence mycoplasmalike organism (MLO) and evidence for relatedness with aster yellows MLOs. Petria 2:184-193.

5. Gibb, K. S., Padovan, A. C., and Mogen, B. D. 1995. Studies on sweet potato little-leaf phytoplasma detected in sweet potato and other plant species growing in northern Australia. Phytopathology 85:169-174.

6. Griffiths, H. M., Gundersen, D. E., Sinclair W. A., Lee, I.-M., and Davis, R. E. 1994. Mycoplasmalike organisms from milkweed, goldenrod, and spirea represent two new $16 \mathrm{~S}$ rRNA subgroups and three new strain subclusters related to peach X-disease MLOs. Can. J. Plant Pathol. 16:255-260.

7. Gundersen, D. E., Lee, I.-M., Rehner, S. A., Davis, R. E., and Kingbury, D. T. 1994. Phylogeny of mycoplasmalike organisms (phytoplasmas): A basis for their classification. J. Bacteriol. 176:5244:5254.

8. Kato, S., and Iwanami, S. 1989. Occurrence of eggplant dwarf in Aichi Prefecture and host range of its causal mycoplasmalike organism. Proc. Kanto-Tosan Plant Prot. Soc. 36:46-49.

9. Kato, S., and Iwanami, S. 1990. Tsuwabuki witches' broom occurring in Nichinan City. (Abstr.) Ann. Phytopathol. Soc. Jpn. 56:394.

10. Kato, S., Shiomi, T., Wakibe, H., and Iwanami, S. 1988. Tomato yellows transmitted by the leafhopper vector, Macrosteles orientalis Virvaste. Ann. Phytopathol. Soc. Jpn. 54:220-223.

11. Kato, S., Uematsu, S., and Iwanami, S. 1991. White lace flower (Ammi majus) yellows and 
marguerite MLO disease occurring in Chiba Prefecture. (Abstr.) Ann. Phytopathol. Soc. Jpn. 57:75.

12. Koike, K., Okuda, S., and Orita, S. 1973. Symptoms and insect transmission of gentian witches' broom. Proc. Assoc. Plant Prot. Hokuriku 21:111-115.

13. Lee, I. M., Davis, R. E., Chen, T.-A., Chiykowski, L. N., Fletcher, J., Hiruki, C., and Schaff, D. A. 1992. A genotype-based system for identification and classification of mycoplasmalike organisms (MLOs) in the aster yellows MLO strain cluster. Phytopathology 82:977-986.

14. Lee, I.-M., Hammond, R. W., Davis, R. E., and Gundersen, D. E. 1993. Universal amplification and analysis of pathogen 16S rDNA for classification and identification of mycoplasmalike organisms. Phytopathology 83:834-842.

15. Lim, P. O., and Sears, B. B. 1989. 16S rRNA sequence indicates that plant-pathogenic mycoplasmalike organisms are evolutionarily distinct from animal mycoplasmas. J. Bacte- riol. 171:5901-5906.

16. Namba, S., Kato, S., Iwanami, S., Oyaizu, H., Shiozawa, H., and Tsuchizaki, T. 1993. Detection and differentiation of plant-pathogenic mycoplasmalike organisms using polymerase chain reaction. Phytopathology 83:786-791.

17. Namba, S., Oyaizu, H., Kato, S., Iwanami, S., and Tsuchizaki, T. 1993. Phylogenetic diversity of phytopathogenic mycoplasmalike organisms. Int. J. Syst. Bacteriol. 43:461-467.

18. Okuda, S. 1977. Studies on the causal agents of yellows or witches' broom diseases of plants. College of Agriculture, Utsunomiya University, Japan Bull. 32:1-70.

19. Okuda, S., Doi, Y., Yora, K., Asuyama, H., and Komuro, Y. 1968. Mitsuba witches' broom caused by mycoplasma-like organism. (Abstr.) Ann. Phytopathol. Soc. Jpn. 34:349.

20. Okuda, S., Kishi, K., Doi, Y., and Yora, K. 1972. Lettuce yellows top necrosis, gentian witches' broom, and garland chrysanthemum witches' broom. (Abstr.) Ann. Phytopathol. Soc. Jpn. 38:215.
21. Okuda, S., and Nishimura, N. 1974. Witches' broom of Cryptotaenia japonica Hassk. Ann Phytopathol. Soc. Jpn. 40:439-451.

22. Schneider, B., Ahrens, U., Kirkpatrick, B. C. and Seemuller, E. 1993. Classification of plant pathogenic mycoplasma-like organisms using restriction site analysis of the PCR-amplified 16S rDNA. J. Gen. Microbiol. 139:519-527.

23. Shiomi, T. 1988. Host range of gentian witches' broom MLO and transmission by Scleroracus flavopictus. Proc. Kansai Plant Prot. Soc. 30:31-36.

24. Shiomi, T., and Sugiura, M. 1984. Grouping of mycoplasma-like organisms transmitted by the leafhopper vector, Macrosteles orientalis Virvaste, based on host range. Ann. Phytopathol. Soc. Jpn. 50:149-157.

25. Shiomi, T., and Sugiura, M. 1984. Differences among Macrosteles orientalis-transmitted MLO, potato purple-top wilt MLO in Japan, and aster yellows MLO from USA. Ann Phytopathol. Soc. Jpn. 50:455-460. 